\title{
Niepełnosprawność jako zjawisko społeczne i stan indywidualny osoby niepełnosprawnej (ze szczególnym uwzględnieniem osób głuchoniewidomych)
}

\section{Disability as a social phenomenon and a individual state of a disabled person (with special consideration of deaf-blind people)}

\author{
Marzenna Zaorska \\ Uniwersytet Warmińsko-Mazurski w Olsztynie, Wydział Nauk Społecznych, Katedra Pedagogiki Specjalnej, \\ Olsztyn
}

Adres autora: Marzenna Zaorska, Uniwersytet Warmińsko-Mazurski, Wydział Nauk Społecznych, ul. Żołnierska 14, 10-561 Olsztyn, e-mail: mzaorska@poczta.onet.pl

\begin{abstract}
Streszczenie
Kwestie interpretacji i możliwie pełnej identyfikacji problematyki niepełnosprawności do dzisiaj wywołują ożywione dyskusje wśród specjalistów zajmujących się działaniami na rzecz osób niepełnosprawnych i środowisk z nimi związanych. Zwraca się uwagę nie tylko na ogólnospołeczny i indywidualny wymiar danego zagadnienia, lecz także na różnorodne uwarunkowania decydujące o podejściu do interpretacji wskazanych wymiarów. Stąd w artykule podjęto próbę opisu zagadnienia niepełnosprawności jako zjawiska społecznego i stanu indywidualnego, jak również wybranych cech każdej z zasygnalizowanych płaszczyzn problematyki niepełnosprawności. Dokonano także przeniesienia realizowanej narracji na konkretne uwarunkowania rozwoju oraz indywidualnego i społecznego funkcjonowania osób z równoczesnym uszkodzeniem słuchu i wzro$\mathrm{ku}$ (głuchoniewidomych).
\end{abstract}

Słowa kluczowe: niepełnosprawność • osoba niepełnosprawna • wymiary niepełnosprawności • modele niepełnosprawności - zjawisko niepełnosprawności • stan niepełnosprawności • osoby głuchoniewidome

\section{Abstract}

The issues of interpretation and the most likely identification of the problematic aspects of disability, up to present days, bring forth lively discussions among the specialists working for the benefit of disabled people and environments tied to them. Not only the social and individual aspect of a certain problem is highlighted, but so are different determinants which decide about the approach to the interpretation of chosen issues. Thus, the article undertakes an attempt of describing the topic of disability as an individual state and social phenomenon, but also chosen characteristics of each highlighted areas of problematic aspects of disability. The article also describes certain determinants of development and individual and social functioning of people with simultaneous hearing and sight impairment (deaf-blind).

Key words: disability $\bullet$ disabled person $\bullet$ different dimensions of disability $\bullet$ different forms of disability $\bullet$ phenomenon of disability $\bullet$ state of being disabled $\bullet$ deaf-blind people

\section{Wprowadzenie}

Zarówno współczesna, jak i historyczna pedagogika specjalna, tak w kontekście teoretycznym, ale przede wszystkim praktycznym, koncentrowała szczególną uwagę naukowo-badawczą i czynnościową, behawioralną, (re)habilitacyjno-edukacyjno-wspomagającą na kwestii najważniejszej dla realizowanych działań specjalistycznych i prowadzonego dyskursu koncepcyjnego - na osobie niepełnosprawnej, jej potrzebach indywidualnych oraz społecznych. To człowiek niepełnosprawny był, i jest, dla pedagogiki specjalnej zagadnieniem najważniejszym $\mathrm{w}$ perspektywie poszukiwania racjonalnego, maksymalnie możliwego, celowego i adekwatnego do osobistych potrzeb, zindywidualizowanego oraz ogólnospołecznego wsparcia. Stąd problematyka niepełnosprawności zawsze stała w centrum wszelakich rozważań i działań ludzi powiązanych $\mathrm{z}$ osobami niepełnosprawnymi poprzez więzy 
rodzinne lub zawodowe. Powiązaniom tym przyświecał, i nadal przyświeca, nadrzędny cel, którym jest taka interpretacja zagadnienia niepełnosprawności, aby wiodła $\mathrm{ku}$ prawdziwemu poznaniu jej istoty, $\mathrm{z}$ równoczesnym uwzględnieniem wszystkich możliwych uwarunkowań decydujących o życiu osoby niepełnosprawnej.

Oczywiste jest, że zarówno w aspekcie historycznym, jak i współczesnym na niepełnosprawność, zasadność istnienia niepełnosprawności i możliwości ludzi niepełnosprawnych patrzono i patrzy się w sposób nieidentyczny. Nieidentyczność owa uzależniona jest zasadniczo od poziomu rozwoju cywilizacji, jakości życia ludzkiego w określonej epoce historycznej, dominujących poglądów filozoficznych i religijnych czy stanu wiedzy na temat przyczynowości pojawiania się niepełnosprawności, jej ewentualnych konsekwencji, możliwości ich zminimalizowania, przydatności osób niepełnosprawnych dla społecznego ogółu i wkładu niepełnosprawnych w rozwój cywilizacyjny. Stąd na przestrzeni dziejów niepełnosprawność i osoby niepełnosprawne postrzegano $\mathrm{z}$ różnych punktów widzenia, co kolejno egzemplifikowało się w konkretnych działaniach realizowanych na ich rzecz.

Nie ulega również wątpliwości fakt, że niepełnosprawność była (dla wielu osób pełnosprawnych niestety nadal jest) specyficznym, zasadniczo negatywnym stygmatem, etykietą mniejszych możliwości, mniejszej wartości, niższej przydatności dla społeczeństwa i rozwoju ludzkości. Etykietą informującą o potrzebie łożenia zwiększonych środków i spotęgowanego wysiłku ze strony ludzi pełnosprawnych na utrzymanie osób niepełnosprawnych, przy założeniu, że nakłady te zapewne nigdy nie zostaną zwrócone. Stąd nie tylko określone postawy społeczne wobec niepełnosprawności i osób niepełnosprawnych, z dominacją nastawień negatywnych, lecz także podejście do interpretacji zagadnienia niepełnosprawności, z koncentracją na podejściu bardziej wygodnym w określonym okresie historycznym. Polega to na uwypuklaniu tych komponentów niepełnosprawności, które w danym czasie są bardziej pożądane i wygodniejsze z punktu widzenia bardziej sprawnej większości, ze względu na kosztowność proponowanych rozwiązań pomocowych. Wskazane podejście oczywiście nie służy prawdziwemu opisowi problemu niepełnosprawności, a jedynie konstruuje asekuracyjne dla konkretnych czasów widzenie danego zagadnienia. Ponadto powoduje popadanie ze skrajności w skrajność poprzez generalizację, wyrażaną w gloryfikacji, określonego komponentu niepełnosprawności i bagatelizowaniu, minimalizowaniu, a nawet odrzucaniu innych komponentów, równie ważnych i istotnych oraz służących osobom niepełnosprawnym i działaniom podejmowanym na rzecz charakterystyki sytuacji rozwojowej, funkcjonalnej, życiowej ludzi niepełnosprawnych. Nie służy prawdziwości starań podejmowanych w celu poznawania rozwiązań pomocowych adresowanych do osób niepełnosprawnych.

Przedstawiona niekonsekwencja w kontekście historycznym uwidaczniała się zasadniczo w opieraniu analiz dylematu niepełnosprawności na jej biologicznym wymiarze, z jednoczesną minimalizacją, a nawet pomijaniem, wymiaru społecznego. Efektem wskazanej tendencji było ukierunkowanie na analizę przyczyn niepełnosprawności oraz ich efektów w optyce etiologicznej, tzn. objawów już obecnych i jeszcze nieobecnych, ale z założeniem, że zapewne w bliższym lub dalszym czasie się ujawnią. Ponadto w dostosowywaniu planowanych i rzeczywiście wykonywanych zaleceń oraz strategii pomocowych (medycznych, psychologiczno-pedagogicznych, (re)habilitacyjno-terapeutycznych, społecznych) do etiologii, ograniczeń, trudności i niemożności wynikających z niepełnosprawności. Także w nacelowaniu na organizację specjalnej pomocy systemowej na płaszczyźnie kształcenia, aktywności społeczno-zawodowej, sportowo-rekreacyjnej czy kulturalno-artystycznej. Również w działaniach skoncentrowanych na organizacji specjalnych, postrzeganych obecnie jako izolacyjne, nieintegracyjne, form pomocy rehabilitacyjno-edukacyjnej, społecznej i zawodowej, wielokrotnie ulokowanych przestrzennie na marginesie obszarów zarezerwowanych dla dominującej sprawnej większości.

Aktualnie, jako rezultat zmian cywilizacyjnych, rozwoju nauki i techniki, zwiększającej się jakości życia ludzi, ukierunkowania na większą humanizację w podejściu do potrzeb współczesnego człowieka i sensu jego indywidualnego życia, na podmiotową interpretację jego społecznej i osobistej aktywności, dominujące znaczenie, ale też znaczenie o charakterze generalizująco-gloryfikującym, zyskuje społeczne podejście do zagadnienia ludzkiej niepełnosprawności. Czasami (i wcale nie aż tak rzadko) podejście to posiada znamiona dominacji nad innymi możliwymi alternatywami. Zasadniczo chodzi o to, że kontekst społeczny niepełnosprawności uzyskuje często postać skrajną i przejawia się w formie totalnej krytyki, naznaczania niesłusznością i nieprawdziwością, jawnego odrzucania i piętnowania (także tych sprzeciwiających się danej sytuacji) postulatów głoszących potrzebę również biologicznego widzenia niniejszego problemu. Sądzić w tym miejscu można, że wskazane zachowania mogą posiadać, i przeważnie posiadają, determinantę obejmującą fakt bycia politycznie poprawnym, przypodobania się tendencjom bardziej akceptowanym lub determinantę związaną z realizacją własnych planów poprzez popieranie poglądów będących na czasie, modniejszych, a przy tym w większym stopniu umożliwiających osiągnięcie stawianych sobie celów własnych.

Pierwsza koncepcja, proponująca większe uwzględnienie społecznego wymiaru niepełnosprawności (co niesłusznie zostało zrozumiane jako pewne odejście od wymiaru biologicznego), pojawiła się w roku 1980 pod nazwą Klasyfikacja Uszkodzeń, Niepełnosprawności i Upośledzeń. Została zaakceptowana i rozpropagowana przez Światową Organizację Zdrowia. Eksponowała identyfikację niepełnosprawności z punktu widzenia trzech możliwych i generalnie istotnych dla rozwoju oraz funkcjonowania osoby niepełnosprawnej wymiarów: uszkodzenia (oznacza wszelki brak lub anormalność psychologicznej, fizjologicznej lub anatomicznej struktury lub funkcji organizmu na skutek określonej wady wrodzonej, choroby lub urazu), niepełnosprawności biologicznej (oznacza ograniczenie lub brak, wynikający z uszkodzenia, zdolności do wykonywania czynności w sposób i w zakresie uważanym za normalny dla człowieka) i upośledzenia - niepełnosprawności społecznej (oznacza mniej korzystną sytuację danej osoby, wynikającą z uszkodzenia lub niepełnosprawności, która ogranicza lub uniemożliwia wypełnianie ról związanych z jej wiekiem, płcią oraz sytuacją społeczną 
i kulturową) [1]. Zaprezentowane podejście w kolejnych latach było dość mocno krytykowane z racji zbytniego akcentowania medycznego aspektu niepełnosprawności. Dlatego w roku 2001 Światowa Organizacja Zdrowia przyjęła nową Międzynarodową Klasyfikację Funkcjonowania, Niepełnosprawności i Zdrowia - ICF (ang. International Classification of Functioning, Disability and Health). Obecna klasyfikacja, jak sygnalizują jej zwolennicy i propagatorzy, ujmuje wzajemne relacje między zdrowiem, funkcjonowaniem i niepełnosprawnością organizmu, a także uczestnictwem człowieka w życiu społecznym. Przyjmuje bio-psycho-społeczny model niepełnosprawności i nie ogranicza się wyłącznie do wymiaru biologicznego (medycznego). Podstawowym oraz wyjściowym pojęciem dla analizy zagadnienia niepełnosprawności czyni pojęcie zdrowia, rozumiane jako stan zdrowia, tj. dobrostan (dobre samopoczucie), obejmujący całokształt dziedzin życia ludzkiego wraz z fizycznymi, psychicznymi i społecznymi aspektami włącznie, które tworzą to, co nazywa się „dobrym życiem”. Następne co do ważności jest pojęcie funkcjonowania człowieka, obejmujące takie jego składniki, jak: funkcjonowanie organizmu, aktywność człowieka oraz jego uczestnictwo w życiu społecznym. Oznacza pozytywne aspekty wzajemnych relacji pomiędzy osobą z określonym stanem zdrowia a czynnikami wypływającymi z kontekstu (sytuacji), w którym osoba ta się znajduje. Konkretnie chodzi tu o czynniki środowiskowe i cechy osobowe, które mają wpływ na tzw. dobre funkcjonowanie człowieka. Trzecie w kategoryzacji ważności jest pojęcie niepełnosprawności definiowane jako utrudnienie, ograniczenie lub uniemożliwienie aktywności człowieka i jego uczestnictwa w życiu społecznym. Określa więc negatywne aspekty interakcji pomiędzy osobą a czynnikami wypływającymi z kontekstu, w którym osoba się znajduje. Niepełnosprawność w ramach wskazywanej koncepcji posiada trzy podstawowe wymiary: biologiczny, indywidualny i społeczny. Odchylenie w poszczególnych wymiarach może więc przyjąć trzy wynikające $\mathrm{z}$ nich poziomy/formy niepełnosprawności. Na poziomie biologicznym jest to: zniesienie, ograniczenie lub zaburzenie przebiegu funkcji organizmu w zależności od stopnia i zakresu uszkodzenia jego organów lub układów. Na poziomie indywidualnym (jednostkowym) lub osobowym jest to ograniczenie aktywności. Na poziomie społecznym - to ograniczenie uczestnictwa w życiu społecznym, czyli społecznego funkcjonowania. Ponadto podkreśla się, że szczególne znaczenie dla danej koncepcji niepełnosprawności ma uwzględnienie czynników kontekstowych bezpośrednio rzutujących na jej powagę, na jej doświadczanie i poczucie obecnych ograniczeń, a mianowicie: czynników środowiskowych i indywidualnych - cech osobistych (Międzynarodowa Klasyfikacja Funkcjonowania, Niepełnosprawności i Zdrowia - ICF oraz jej zastosowanie) $[1,2]$.

Zwolennicy opisywanej koncepcji sugestywnie podkreślają, iż stara się ona uwzględnić dwa ścierające się modele niepełnosprawności: model medyczny - akcentujący głównie medyczny, biologiczny i osobisty charakter niepełnosprawności oraz model społeczny - identyfikujący niepełnosprawność zasadniczo w aspekcie barier tkwiących w fizycznym i społecznym środowiska człowieka niepełnosprawnego. Przy czym, a tak wynika z proponowanej kategoryzacji terminów istotnych dla opisu niepełnosprawności, skłaniają się ku uznaniu pierwszorzędowości społecznego podejścia do niepełnosprawności z równoczesnym odejściem od komponentów biologicznych jako naznaczających, etykietujących stan ludzkiej niepełnosprawności.

Przedstawione wyżej widzenie zagadnienia niepełnosprawności egzemplifikuje się, poza preferencją jej społecznego modelu, w definicjach niepełnosprawności proponowanych w istotnych dla osób niepełnosprawnych dokumentach i aktach prawnych, co z kolei przenosi się na istotę, ukierunkowanie i sposób realizacji działań pomocowych adresowanych do osób z niepełnosprawnością, z nacelowaniem na komponent społeczny jako zasadniczy, podstawowy, przesądzający o rozwoju, funkcjonowaniu i aktywności osobistej oraz społecznej osób niepełnosprawnych. Przykładem może być definicja podana w Europejskiej strategii w sprawie niepetnosprawności 2010-2020: Odnowione zobowiązanie do budowania Europy bez barier, powołująca się na interpretację niepełnosprawności wskazaną w Konwencji o prawach osób niepetnosprawnych, ONZ 2006: „Do osób niepełnosprawnych zalicza się te osoby, które maja długotrwale naruszoną sprawność fizyczną, umysłową, intelektualną lub sensoryczną, co może, w oddziaływaniu $\mathrm{z}$ różnymi barierami, utrudniać im pełne i skuteczne uczestnictwo w życiu społecznym, na równych zasadach z innymi osobami" [3]. Podobną sytuację dostrzegamy w definicji osoby niepełnosprawnej przyjętej w Uchwale Sejmu RP z 1 sierpnia 1997 r. - Karta Praw Osób Niepełnosprawnych: „Niepełnosprawne są osoby, których sprawność fizyczna, psychiczna lub umysłowa trwale lub okresowo utrudnia, ogranicza lub uniemożliwia życie codzienne, naukę, pracę oraz pełnienie ról społecznych, zgodnie z normami prawnymi i zwyczajowymi” [4].

Powstaje w tym miejscu pytanie, czy zasygnalizowana sytuacja służy prawdziwości identyfikacji niepełnosprawności, prawdziwości i celowości działań oferowanych osobom niepełnosprawnym. Pojawia się hipotetycznie możliwa odpowiedź, iż nie. Minimalizuje się bowiem (a chwilami pomija wręcz) biologiczne konteksty, korelaty i aspekty stanu osoby ludzkiej lub ich po prostu nie dostrzega. Stąd, jeśli w kontekście historycznym gloryfikacja biologicznego wymiaru niepełnosprawności może być usprawiedliwiona argumentami poziomu wiedzy na temat niepełnosprawności, możliwości naukowych, technicznych i ekonomicznych społeczeństwa, dominujących koncepcji filozoficznych i nurtów religijnych, to sytuacja odmienna, charakteryzująca się nadrzędnością kontekstu społecznego, w społeczeństwie wysoce cywilizowanym nie znajduje klarownego uzasadnienia. Jedynym takim uzasadnieniem jest podejście ekonomiczne z zamiarem maksymalnego ograniczania kosztowności, którą może generować problem niepełnosprawności ze strony dominującego ogółu wpisującego się w przyjęte przez siebie standardy normy, standardy uznane na pożądany wskaźnik ludzkiego funkcjonowania i to nie tyle biologicznego, ile właśnie społecznego.

Dlatego pojawia się myśl o potrzebie identyfikacji niepełnosprawności w kategoriach równorzędności i równowartości komponentów tworzących niepełnosprawność, jej hipotetycznie możliwych wymiarów i aspektów jako argument sprzyjający bardziej obiektywnemu, prawdziwemu i wiarygodnemu widzeniu oraz zrozumieniu istoty analizowanego stanu. A to wszystko powinno służyć nie 
tylko ludziom niepełnosprawnym, lecz także pełnosprawnym, bowiem podejmowane przez nich działania uzyskają swoją celowość, optymalizację i racjonalizację zarówno w wymiarze czysto humanistycznym, humanitarnym, jak i ekonomicznym.

\section{Niepełnosprawność jako zjawisko społeczne}

Na zagadnienie ludzkiej niepełnosprawności, zarówno w aspekcie historycznym, współczesnym, jak i perspektywicznym można i należy spojrzeć w płaszczyźnie jego społecznych uwarunkowań oraz społecznych egzemplifikacji. Oznacza to, że dotyczyło ono, i nadal dotyczy, określonego (mniejszego lub większego, zależnie od okresu historycznego) odsetka populacji, co było i jest determinowane jakością opieki medycznej, poziomem jakości życia ludzi, jak również postawami ogólnospołecznymi wobec dylematu niepełnosprawności globalnie oraz osób niepełnosprawnych konkretnie, wyznaczanymi dominującymi koncepcjami filozoficznymi, poglądami religijnymi, stanem wiedzy na temat przyczynowości niepełnosprawności, jej konsekwencji, możliwości indywidualnej i społecznej aktywności osób niepełnosprawnych, stycznością z niepełnosprawnością oraz osobami niepełnosprawnymi. Ponadto istotną kwestią jest przydatność ludzi niepełnosprawnych dla społeczeństwa ilościowo i odsetkowo zdominowanego przez osoby pełnosprawne oraz wkład niepełnosprawnych w rozwój społeczny, naukowy, techniczny, w poprawę poziomu jakości życia ludzkiego.

Biorąc pod uwagę wskazane uwarunkowania tematyki niepełnosprawności jako zjawiska społecznego, zarówno $\mathrm{w}$ aspekcie historycznym jak i współczesnym, można analizować niniejsze zagadnienie z ilościowego i jakościowego oraz merytorycznego punktu widzenia. Także z perspektywy osób postrzegających siebie jako zdrowe i pełnosprawne oraz osób niepełnosprawnych i środowisk z nimi związanych. Dodatkowo w korelacie historycznym, aktualistycznym i perspektywicznym.

Ilościowa analiza problematyki niepełnosprawności koncentruje się zasadniczo na jej rozmiarach, statystycznych wskaźnikach obecności niepełnosprawności i osób niepełnosprawnych $\mathrm{w}$ relacji do osób uznanych za pełnosprawne oraz koresponduje ściśle z potrzebą okazywania specjalnej, przeważnie wzmożonej pomocy specjalistycznej w obszarze:

- opieki medycznej, psychofizycznego usprawniania, aktywizacji społecznej, (re)habilitacji szeroko rozumianej jako fizyczna, psychiczna i społeczna,

- edukacji dostosowanej do indywidualnych możliwości, - wielozakresowej, różnorodnej i wszechstronnej pomocy w życiu dorosłym o charakterze socjalnym, rodzinnym, zawodowym, kulturalno-rekreacyjnym,

- dostosowania przestrzeni i infrastruktury otoczenia oraz jej funkcjonowania do potrzeb osób niepełnosprawnych.

Wskazane potrzeby wiążą się z koniecznością ponoszenia określonych, niemałych nakładów, zasadniczo finansowych, na zapewnienie osobom niepełnosprawnym możliwie aktywnego życia osobistego i społecznego, co oznaczać może ograniczanie wydatków na inne, ważne z punktu widzenia większości społeczeństwa działania i zadania, które służą rozwojowi cywilizacyjnemu oraz poprawie jakości życia ludzi. To może wywoływać sprzeciw, jeśli nie większości, to zapewne części pełnosprawnych członków społeczeństwa, szczególnie społeczeństwa ukierunkowanego na konsumpcję i zaspokajanie własnych potrzeb, oraz nieprzyjmowanie argumentów dotyczących potrzeby zachowań humanistycznych, humanitarnych, społecznej lojalności czy odpowiedzialności zbiorowej tych bardziej sprawnych za sprawnych mniej.

Ilościowe i jakościowe społeczne percepcje zjawiska niepełnosprawności mogą uzyskiwać przełożenie na merytoryczne podejście do danego zagadnienia, które polega na postrzeganiu niepełnosprawności, osób niepełnosprawnych, ich możliwości indywidualnych i wkładu w rozwój społeczny i jest wyrażane w postawach społecznych wobec dylematu niepełnosprawności, osób niepełnosprawnych oraz w działaniach realizowanych na ich rzecz w sposób jawny lub ukryty.

Nacelowanie na kwestie zrozumienia zjawiska niepełnosprawności i sytuacji osób niepełnosprawnych obejmuje podejście empatyczne, akceptujące, tendencje racjonalnej identyfikacji potrzeb i racjonalnych działań pomocowych przy równoczesnej aprobacie dla ponoszenia wymaganych kosztów na zapewnienie stosowanego wsparcia nie tylko samym niepełnosprawnym, lecz także osobom rodzinnie i zawodowo $\mathrm{z}$ nimi powiązanym. To również zdroworozsądkowa interpretacja problematyki niepełnosprawności charakteryzująca się szerokim widzeniem jej uwarunkowań biologicznych, indywidualnych i społecznych, egzemplifikująca się w wyważonym i równoprawnym uwzględnianiu każdego elementu warunkującego stan niepełnosprawności, co konstatuje się w niepodkreślaniu i niegloryfikowaniu któregoś z nich jako nadrzędnego.

Nacelowanie na brak zrozumienia zjawiska niepełnosprawności i sytuacji osób niepełnosprawnych może posiadać charakter jawny lub ukryty. Globalnie charakteryzuje się identycznymi cechami. Różnica polega na odmiennym sposobie komunikowania poglądów o niniejszej tematyce. Wśród cech braku zrozumienia zagadnienia niepełnosprawności i osób niepełnosprawnych można wskazać jej/ich postrzeganie jako ciężaru społecznego, indywidualnego, ekonomicznego, psychoemocjonalnego, komunikacyjnego, wizualnego, zachowanie z celowością ilościowego ograniczania rozmiarów niepełnosprawności w sposób jawny, tzn. poprzez jednoznaczne i niezafałszowane artykułowanie swoich poglądów, lub ukryty, tzn. poprzez eksponowanie społeczno-indywidualnych uwarunkowań niepełnosprawności $\mathrm{z}$ równoczesnym minimalizowaniem uwarunkowań biologicznych. Działania zdefiniowane jako brak zrozumienia dla niepełnosprawności i osób niepełnosprawnych mogą być obecne nie tylko w konkretnych rozwiązaniach pomocowych (w tym w nakładach finansowych), lecz także w promowanych koncepcjach czy definicjach niepełnosprawności popularyzujących niepełną, co oznacza fragmentaryczną i nieadekwatną, percepcję jej możliwych uwarunkowań (stanowi ukryty argument dla ograniczania środków wydatkowanych na potrzeby osób niepełnosprawnych).

W korelacie historycznym i aktualistycznym zagadnienie niepełnosprawności eksponuje się $\mathrm{w}$ stosunku ludzi żyjących w poszczególnych epokach historycznych wobec osób niepełnosprawnych, w poszanowaniu ich praw 
i godności oraz akceptacji dla bycia i życia niepełnosprawnych w społeczeństwie. Korelat perspektywiczny natomiast, poza wskazanymi cechami, włącza ponadto argumenty postępu naukowo-technicznego, zmiany systemu wartości oraz życiowych preferencji ludzi żyjących w czasach niespotykanego dotychczas skoku cywilizacyjnego. Łączy się z możliwościami wykorzystania sukcesów naukowo-technicznych w celu ograniczania rozmiarów niepełnosprawności poprzez nowatorskie metody leczenia wielu schorzeń (np. z wykorzystaniem komórek macierzystych, implantowania, przeszczepiania narządów, wydruku narządów na drukarkach 3D itd.), badania profilaktyczne (w tym badania genetyczne maskujące eugenikę), kult dla ciała i fizycznego piękna, promowanie maksymalizacji długości ludzkiego życia w pełni zdrowia i sprawności jako alternatywy dla życia niezdrowego i niesprawnego, które postrzegane jest jako życie bez sensu dla konkretnego człowieka i społeczeństwa, w którym ów człowiek żyje.

\section{Niepełnosprawność jako stan indywidualny}

Zagadnienie niepełnosprawności niewątpliwie posiada nie tylko wymiar społeczny, lecz także odnosi się do osoby $z$ niepełnosprawnością oraz do percepcji przez osobę niepełnosprawną swojej niepełnosprawności i wynikających z niej konsekwencji zdrowotnych, sprawnościowych, aktywnościowych, dotyczących pełnienia przypisanych istotom ludzkim różnorodnych ról społecznych, samorealizacji w obszarze osobistym i społecznym.

W zależności od podejścia do własnej niepełnosprawności i siebie osoba niepełnosprawna może w sposób zróżnicowany traktować posiadaną niepełnosprawność, co bezpośrednio egzemplifikuje się $\mathrm{w}$ realizowanych rolach oraz aktywnościach. Najogólniej rzecz ujmując, można sklasyfikować wskazane podejście w trzech niejednoznacznych kategoriach.

Pierwszą jest traktowanie niepełnosprawności i siebie $\mathrm{w}$ perspektywie choroby, tj. zasadniczo w kategoriach skrajnie biologicznych, co przekłada się na sferę osobowości, sprawności i aktywności identyfikowanych zasadniczo w postaci ograniczonych możliwości lub nawet wręcz niemożliwości/niemożności, na oczekiwanie pomocy szczególnej i specjalnej, specjalnego systemu wsparcia, edukacji i (re)habilitacji. Charakterystyczna ponadto jest nadmierna koncentracja na zabieganiu o pomoc medyczną, leczenie oraz minimalizację wysiłku psychofizycznego i społecznego.

Drugą - podejście racjonalne, racjonalistyczne, obiektywne, pozbawione zbędnej przesady co do posiadanej niepełnosprawności oraz doświadczanych konsekwencji niepełnosprawności. Równoważy więc korelat biologiczny i społeczny, bez wyróżniania któregoś z nich jako nadrzędnego. Konsekwencje niepełnosprawności postrzegane są jako pewne ograniczniki utrudniające aktywność indywidualną i społeczną, pełnienie ról, edukację czy samorealizację rodzinną i społeczno-zawodową, ale są to ograniczniki możliwe do zniwelowania, a w wielu przypadkach i sytuacjach nawet do pokonania przy odpowiedniej mobilizacji i determinacji na ich identyfikację, zrozumienie i usunięcie poprzez przekroczenie związanych $\mathrm{z}$ nimi problemów.
Trzecią - jest kategoria przeciwstawna pierwszej. Charakteryzuje się koncentracją na społecznym wymiarze niepełnosprawności oraz niezauważaniu czy bagatelizowaniu wymiaru biologicznego. Przejawia się w niedostrzeganiu stanu własnego zdrowia i braku wymaganych działań na jego rzecz. Osoba traktuje siebie jako osobę zdrową, pełnosprawną, a w podejmowanych czynnościach, aktywnościach oraz rolach konsekwencje obecnej u siebie niepełnosprawności postrzega jako przeszkodę zdeterminowaną ograniczeniami wyłącznie społecznymi. Propaguje więc skrajnie społeczny model niepełnosprawności i nie uwzględnia w nim korelacji biologiczno-medycznych. Stąd szafuje wielokrotnie nie tylko swoim zdrowiem, lecz także życiem, a czasami skazuje siebie na doświadczanie niepowodzeń z powodu niepełnego wywiązywania się lub niewywiązywania się z podejmowanych zadań, wyzwań, ról i aktywności.

Przeprowadzone analizy na temat egzemplifikacji niepełnosprawności jako stanu rozwojowo-funkcjonalnego osoby ludzkiej pozwalają ponadto na wnioskowanie, że posiada on wpływ na sferę funkcjonowania psychicznego (osobistego, osobowego), zdrowotnego, fizycznego (organicznego, biologicznego, sprawnościowego, aktywnościowego) i społecznego (aktywność społeczna, pełnienie ról społecznych) osoby niepełnosprawnej. Funkcjonowanie psychiczne człowieka z niepełnosprawnością, jego osobowość, osobiste widzenie własnej niepełnosprawności warunkowane jest zadatkami wrodzonymi, wpływem otoczenia - szczególnie rodzinnego - na kształtowanie się percepcji siebie i posiadanej niepełnosprawności, własnym, zindywidualizowanym widzeniem siebie jako osoby niepełnosprawnej. Funkcjonowanie zdrowotne to inaczej mówiąc stan zdrowia osoby niepełnosprawnej oraz wynikające ze stanu zdrowia potrzeby obejmujące poprawę lub utrzymanie dotychczasowego poziomu zdrowia, ochronę zdrowia własnego, leczenie medyczne $\mathrm{z}$ uwzględnieniem różnorodnych metod i osiągnięć współczesnej medycyny. Natomiast funkcjonowanie fizyczne osoby niepełnosprawnej determinuje czynnik psychiczny i somatyczny. To nie tylko indywidualna, wynikająca $\mathrm{z}$ cech osobowych, osobista percepcja posiadanej niepełnosprawności i stanu swojego zdrowia, lecz także ich egzemplifikacja w wykazywanej sprawności fizycznej, aktywności fizycznej, racjonalnie uwzględniająca możliwe trudności i ograniczenia. Funkcjonowanie społeczne z kolei uzależnione jest od podanych wyżej sfer doświadczania niepełnosprawności przez osobę niepełnosprawną, tj. sfery psychicznej, somatycznej, fizycznej. Stanowi swoisty korelat, ale też wynik, efekt osobistej wizji własnej niepełnosprawności, łączący się z posiadanym stanem zdrowia i wykazywaną aktywnością fizyczną. Jest wyraźnym apogeum, transmisją i transcendencją danych elementów, argumentowanym nie tylko ogólnospołeczną percepcją zjawiska ludzkiej niepełnosprawności, lecz także percepcją niepełnosprawności przez osobę niepełnosprawną.

\section{Niepełnosprawność jako zjawisko społeczne i stan indywidualny $\mathrm{w}$ przeniesieniu na problemy osób głuchoniewidomych}

Osoby głuchoniewidome w populacji osób niepełnosprawnych stanowią grupę wyjątkową i szczególną nie tylko z powodu stosunkowo niewielkiej skali rozpowszechnienia danego typu niepełnosprawności (przyjmuje się przelicznik dwóch osób głuchoniewidomych na 10 tysięcy 
mieszkańców) [5, s. 79] czy kwalifikacji dotyczącej obecności sprzęgania się uszkodzenia dwóch najważniejszych zmysłów - słuchu i wzroku, ale zasadniczo z powodu ich szerokich i zróżnicowanych konsekwencji rozwojowych, funkcjonalnych, indywidualnych oraz społecznych. Także ze względu na specyficzne potrzeby rehabilitacyjne, edukacyjne, odniesione do zakresu i intensywności wspomagania w codziennym życiu.

Ze względu na ograniczenia zmysłowe, tym bardziej jeśli są one obecne od urodzenia lub wczesnego dzieciństwa, osoby głuchoniewidome doświadczają poważnych trudności w dostępie do informacji, wiedzy i nauki, w porozumiewaniu się $\mathrm{z}$ otoczeniem, wykonywaniu czynności życia codziennego, orientacji i poruszaniu się w przestrzeni, edukacji i pracy zawodowej, obejmujących udział człowieka w życiu kulturalnym i społecznym [6].

W tym miejscu można podkreślić, że obecność równoczesnego poważnego uszkodzenia słuchu i wzroku w sposób sobie właściwy determinuje rozwój oraz funkcjonowanie osoby głuchoniewidomej. Sytuacja ludzi nabywających niepełnosprawność w późniejszym okresie życia jest o wiele bardziej komfortowa w porównaniu z ludźmi doświadczającymi konsekwencji sprzęgania się danych uszkodzeń od urodzenia lub wczesnego dzieciństwa. W przypadku tych pierwszych działania edukacyjno-(re)habilitacyjne nakierowane są przede wszystkim na akceptację zaistniałej niepełnosprawności (psychoterapia), jak również na ukształtowanie nowych umiejętności w zakresie orientacji i poruszania się w przestrzeni, realizacji czynności samoobsługowych i czynności życia codziennego, odbioru i przekazywania informacji metodami zastępczymi (terapia logopedyczna, (re)habilitacja społeczna). Inna też jest sytuacja osób z niecałkowitymi uszkodzeniami, posiadają one bowiem określone, częściowe możliwości wykorzystania nie w pełni sprawnych narządów lub funkcji (np. resztek słuchu czy wzroku) w różnych okolicznościach życia, w różnych sferach aktywności oraz przy nabywaniu ważnych umiejętności, niezbędnych w konkretnych sferach egzystencji. Jeszcze inna jest sytuacja osób z mniejszymi uszkodzeniami w jednym zakresie i większymi w innym zakresie - dzięki wykorzystaniu bardziej sprawnego narządu można istotnie ułatwiać działania codzienne, zdobywać wiedzę, realizować ambicje osobiste, rodzinne, zawodowe i społeczne. Niewątpliwie najbardziej skomplikowana jest sytuacja osób mających sprzężone uszkodzenia słuchu i wzroku o charakterze wrodzonym lub wcześnie nabytym. Stąd można pokusić się o podanie ogólnej charakterystyki takich osób w zakresie poznawania otaczającej rzeczywistości, orientacji i poruszania się w przestrzeni, komunikacji, realizacji czynności samoobsługowych i czynności związanych z życiem codziennym, odpoczynku, rekreacji oraz rozwijania zainteresowań.

\section{Poznanie otaczającej rzeczywistości}

Podstawowymi zmysłami umożliwiającymi ludziom rozwój i poznanie rzeczywistości przyrodniczej, przedmiotowej, społecznej są słuch oraz wzrok. W sytuacji osób głuchoniewidomych dominują inne zmysły, te mniej istotne w sensie rozwojowo-poznawczym: dotyk, węch, smak, zmysł wibracji i inne. Oczywiście stan sprzężonych uszkodzeń (szczególnie od urodzenia lub wczesnego dzieciństwa) stwarza dość poważne bariery w odbiorze, rozumieniu i interpretacji postrzeganego, w budowaniu pojęć (przede wszystkim abstrakcyjnych), w zdobywaniu wiedzy teoretycznej oraz praktycznej o życiu, historii cywilizacji, jej kulturze i współczesności. Nie neguje jednak możliwości zdobycia wiedzy za pomocą pozostałych zmysłów, na odmiennych zasadach, z zastosowaniem alternatywnych sposobów pozyskiwania tego wszystkiego, co ludziom pełnosprawnym dane jest na drodze naturalnego, realizowanego poprzez naśladownictwo rozwoju. Stąd specjalnie organizowana przez innych, a często też przez innych kierowana aktywność poznawcza, wykorzystująca sprawne lub bardziej sprawne zmysły, zachętę do działania, zaufanie oraz dodatnie relacje emocjonalne $\mathrm{z}$ osobą prowadzącą proces (re)habilitacyjno-edukacyjny, może dać oczekiwane skutki, tj. umożliwia budowanie wiedzy i rozwój dostosowany do specyficznych warunków, w których osoba taka funkcjonuje. Mówiąc inaczej - głuchoniewidome dziecko jest w stanie stworzyć sobie wyobrażenie lalki, a zatem pojęcie lalki jako zabawki, za pomocą bardziej sprawnego zmysłu lub innych zmysłów, np. dotyku, węchu, smaku, odczuć kinestetycznych, i jest w stanie wykorzystywać lalkę w zabawie, a tym samym rozwijać się poprzez aktywność zabawową.

\section{Orientacja i poruszanie się w przestrzeni}

Równoczesne uszkodzenie słuchu i wzroku może istotnie utrudniać, a nawet poważnie ograniczać możliwości orientacji w przestrzeni (bliższej, dalszej, otwartej, zamkniętej), jak również możliwości pokonywania przestrzeni. Znaczące ograniczenia w zakresie orientacji przestrzennej napotykają nie tylko osoby głuchoniewidome od urodzenia lub wczesnego dzieciństwa, lecz także te, które całkowicie lub częściowo utraciły sprawność zmysłów w późniejszym okresie życia. Ci pierwsi odczuwać mogą między innymi obawy, lęk przed podejmowaniem aktywności związanych $\mathrm{z}$ poznawaniem i przemieszczaniem się $\mathrm{w}$ otoczeniu (mimo posługiwania się wymaganym wsparciem, np. białą laską, pomocą psa-przewodnika, systemem GPS) oraz częstokroć mają dość przykre wspomnienia wielu niebezpieczeństw (także traumatycznych) występujących w przestrzeni. Stąd preferują ograniczanie własnej aktywności przestrzennej na rzecz siedzącego trybu życia - co zdaje się w pełni zrozumiałe i wytłumaczalne. Dodatkowo intuicyjnie wyczuwają, że mają mniejszą sprawnością ruchową, dysponując jedynie pozostałymi zmysłami, tj. węchem, smakiem, dotykiem, czuciem kinestetycznym, które w działaniach lokomocyjnych, w działaniach służących orientacji przestrzennej pełnią rolę drugorzędną. Dlatego wiele takich osób, zarówno tych $\mathrm{z}$ niepełnosprawnością wrodzoną, jak i nabytą, wymaga wsparcia (np. tłumaczy-przewodników), ale też innych rozwiązań w sytuacji przemieszczania się bez opieki (np. napisanej na kartce informacji o tym, że jest się osobą głuchoniewidomą i że prosi się o pomoc w przejściu przez ulicę lub doprowadzenie do celu).

\section{Komunikacja $\mathrm{z}$ otoczeniem}

Kwestia komunikacji z otoczeniem stanowi niezwykle istotny, a właściwie nadrzędny problem wszelkich działań edukacyjno-(re)habilitacyjnych realizowanych wobec osób głuchoniewidomych, a szczególnie osób z niepełnosprawnością wrodzoną lub wcześnie nabytą. Bez komunikacji bowiem nie może być mowy o efektywnym rozwoju, o gromadzeniu 
wiedzy czy pozyskiwaniu umiejętności i nawyków znaczących z egzystencjalnego punktu widzenia. Oczywiście niektóre osoby tracące całkowicie lub częściowo sprawność zmysłów słuchu i wzroku czy umiejętność posługiwania się mową artykułowaną w późniejszym okresie życia mogą korzystać z zaadaptowanych metod przekazu informacji, które wcześniej opanowały. Na przykład osoby wywodzące się ze środowiska niesłyszących nabywające uszkodzenie wzroku stosują na ogół język migowy (ideografię i daktylografię - alfabet palcowy, który mogą przekazywać lub odbierać np. do ręki). Osoby wywodzące się ze środowiska niewidomych nabywające uszkodzenie słuchu dysponują możliwością wykorzystania alfabetu Braille’a. Natomiast osoby, które posiadały wcześniej sprawne zmysły słuchu i wzroku oraz opanowały mowę artykułowaną, mogą komunikować się poprzez pisanie liter drukowanych np. na dłoni. Dla każdej z tych grup ważne jest jednak opanowanie również innych, dodatkowych metod komunikacji alternatywnej, by móc je zastosować w zróżnicowanych warunkach relacji interpersonalnych i społecznych (np. w czasie rozmowy $\mathrm{z}$ inną osobą o podobnym typie niepełnosprawności, realizowanej przy okazji np. wspólnej podróży taksówką późnym wieczorem) oraz w kontaktach indywidualnych lub zbiorowych ze środowiskiem niepełnosprawnych wykorzystujących komunikację alternatywną.

Znacznie bardziej skomplikowana jest sytuacja dzieci $\mathrm{z}$ równoczesnym uszkodzeniem słuchu i wzroku od urodzenia lub wczesnego dzieciństwa. Wiele $\mathrm{z}$ nich zmuszone jest do korzystania $\mathrm{z}$ niewerbalnych metod komunikacji. Do takich metod należą między innymi:

1. Język migowy - ideografia (konkretne znaki oznaczające określone pojęcia), daktylografia - alfabet palcowy (dla głuchoniewidomych dysponujących resztkami wzroku przekazywany jest z bliskiej odległości) lub do ręki (przy braku możliwości odbioru daktylografii kanałem wzrokowym) [7].

2. Alfabet Braille’a lub alfabet Braille’a przekazywany do palców (jednoręczny, dwuręczny lub za pomocą tzw. tabliczki brajlowskiej czarnodrukowej - na plastikowej tabliczce znajdują się litery i cyfry wydrukowane pismem wypukłym wraz z oznaczeniami przedstawionymi w postaci pisma płaskiego) [8].

3. Systemy obrazkowe (dla osób dysponujących możliwościami wzrokowymi) - System Komunikacji Obrazkowej PCS [9], piktogramy [10] czy System Bliss [11].

4. Systemy do/na ręki/ręce - alfabet punktowy do dłoni [12], alfabet Lorma [13].

5. Mowa artykułowana odbierana kanałem słuchowym lub za pomocą sposobów zastępczych, np. wyczuwania wibracji wiązadeł głosowych, ruchów warg, policzków i szczęki dolnej poprzez specjalne ułożenie palców dłoni przez osobę niepełnosprawną na twarzy nadawcy komunikatu.

6. Język ciała - komunikacja wykorzystująca mimikę, pantominikę, reakcje wegetatywne (pocenie się, czerwienienie skóry, przyspieszone bicie serca), ruchy, gesty, spojrzenie, pozycję ciała.

\section{Realizacja czynności samoobsługowych i czynności związanych z życiem codziennym}

Obecność równoczesnego, poważnego uszkodzenia słuchu i wzroku może znacząco utrudniać, ograniczać, a także uniemożliwiać realizację czynności samoobsługowych (mycie, ubieranie, pielęgnowanie ciała itd.) oraz czynności związanych z życiem codziennym (przygotowywanie posiłków, sprzątanie, pranie, prasowanie, zakupy itd.). Niewątpliwie w dużej mierze poziom opanowania oraz wykonywania tych czynności uzależniony jest od rodzaju i głębokości uszkodzeń. Nie eliminuje to jednak konieczności specjalnego nauczania sposobu realizacji danych czynności (jeśli jest to możliwe) opartego na treningu (wielokrotnych powtórzeń) wraz z kształtowaniem świadomości potrzeby dostosowywania sposobu ich realizacji do konkretnych sytuacji życia społecznego i indywidualnego. Ważne jest $\mathrm{w}$ miarę samodzielne radzenie sobie $\mathrm{z}$ czynnościami samoobsługowymi (chociażby z uwagi na intymny charakter niektórych $\mathrm{z}$ nich) czy czynnościami życia codziennego (z uwagi na potrzeby biologiczne). Jednak kiedy stan uszkodzeń nie pozwala na pełną samodzielność, niezbędna jest pomoc lub wsparcie ze strony innych osób $z$ otoczenia (rodziny, sąsiadów, pracowników pomocy społecznej, wolontariuszy). Praktyka pokazuje, że większość osób głuchoniewidomych nie tylko jest w stanie opanować na zadowalającym poziomie codzienne czynności samoobsługowe, lecz także nie potrzebuje pomocy przy ich wykonywaniu lub jeśli takiej pomocy wymaga, to jest to zasadniczo pomoc wspierająca.

\section{Odpoczynek, rekreacja oraz rozwijanie zainteresowań}

Ludzie głuchoniewidomi, zarówno dorośli, jak i dzieci, zarówno ci z niepełnosprawnością wrodzoną lub wcześnie nabytą, jak i ci z niepełnosprawnością powstałą w późniejszym okresie życia, ci z całkowitymi uszkodzeniami słuchu i wzroku, jak i ci z uszkodzeniem częściowym potrzebują relaksu, chwil wytchnienia, by zregenerować siły psychiczne i witalne. Potrzebują odpoczynku biernego, ale też czynnego w czasie wolnym. W jaki więc sposób mogą ten swój czas wolny aktywnie spędzać? Odpowiedź jest prosta - podobnie jak osoby pełnosprawne: na spotkaniach z rodziną, przyjaciółmi, znajomymi. Na wycieczkach, rajdach (także w góry), wczasach, turnusach (re)habilitacyjno-wypoczynkowych. Mogą czytać (jeśli opanowali daną umiejętność) ciekawą literaturę, czasopisma sposobem sobie dostępnym lub z pomocą innych osób. Słuchać muzyki (np. stosując systemy bezprzewodowe wzmacniające dźwięki), oglądać telewizję czy korzystać z Internetu (z pomocą urządzeń optycznych oraz specjalnych przystawek do komputera i specjalnego oprogramowania). Mogą rozwijać zainteresowania artystyczne (np. rzeźbienie, wyszywanie, ceramika) czy literackie (w sytuacji posiadania takich zdolności oraz możliwości ich realizacji pisanie wierszy, własnej biografii). Nie istnieją więc jakieś szczególne ograniczenia w tym względzie. Liczy się chęć tworzenia, uruchamiania potencjału własnych możliwości i pokazania go innym.

\section{Istota nadrzędnych problemów rehabilitacji i specjalnej pomocy}

Podstawowym determinantem wszelakich działań specjalistycznych na rzecz osób głuchoniewidomych są postawy społeczne wobec tej kategorii niepełnosprawnych. Decydują one bowiem zarówno o obecności takich działań, jak i o ich jakości i merytorycznym uzasadnieniu ich specyfiki. 
Tak więc postawy społeczne wobec ludzi głuchoniewidomych nie można uznać ani za jednoznacznie pozytywne - oparte na zrozumieniu i chęci pomocy, ani za jednoznacznie negatywne - polegające na niechętnym stosunku lub odrzucaniu obecności tych osób w społeczeństwie, czy jednoznacznie obojętne - charakteryzujące się ambiwalentnymi odczuciami wobec problemów doświadczanych przez dane środowisko ludzkie. Dzieje się tak dlatego, że pełnosprawni na ogół nigdy nie mieli żadnych kontaktów z człowiekiem głuchoniewidomym czy z jego najbliższym otoczeniem społecznym, nie znają sytuacji rozwojowej, funkcjonalnej tych osób oraz ich możliwości. Potrafią jedynie, i to w dużym przybliżeniu, wyobrazić sobie - przeważnie pod kątem ograniczeń, komplikacji, trudności - sytuację takiego człowieka w różnych aspektach życia. Osoby głuchoniewidome dość często wywołują zdziwienie tym, że w ogóle są, że mogą istnieć i żyć wśród nas. Uruchamiają obawy, a nawet lęk przed tym, co można zrobić, jak się zachować w okolicznościach spotkania takiej osoby. Wskazane reakcje nie można wobec powyższego uznać ani za negatywne czy obojętne, a raczej za nacechowane brakiem informacji, wiedzy i dezorientacją na temat danych osób, wiedzy o ich szczególnej sytuacji oraz o tym, jak można nawiązać z nimi kontakt. Stąd bardzo potrzebna jest edukacja społeczeństwa w kwestii ograniczeń doświadczanych przez ludzi głuchoniewidomych, ale przede wszystkim w kwestii nieznanych szerszemu ogółowi ich potencjalnych możliwości osobowych, sprawnościowych, aktywizacyjnych, społecznych.

\section{Podsumowanie}

Problematyka ludzkiej niepełnosprawności, mimo że aktualnie znajduje się w polu szczególnych zainteresowań nie tylko pedagogiki specjalnej, lecz także innych dyscyplin i subdyscyplin wiedzy zajmujących się teoretycznie i praktycznie ukierunkowywaniem, organizacją i realizacją działań na rzecz osób niepełnosprawnych, nie znalazła wymaganej pełni jej zrozumienia i obiektywnej identyfikacji w relacji do społecznego ogółu, tj. jako zjawiska społecznego, i w relacji do osoby niepełnosprawnej, tj. jako zjawiska indywidualnego. Podejmowane próby opisu niepełnosprawności do chwili obecnej cechują liczne ograniczenia historyczne, mentalne, filozoficzne, religijne, koncepcyjne. Ich wymiernym rezultatem jest swoista obranemu punktowi widzenia identyfikacja niepełnosprawności z równoczesnym podkreślaniem, charakterystycznym dla tego punktu widzenia, jej podstawowych cech i możliwych uwarunkowań. Zwraca się więc szczególną uwagę na uwarunkowania społeczne, marginalizując lub pomijając przy tym uwarunkowania biologiczne i indywidualne, lub odwrotnie - koncentruje się na którymś z podanych uwarunkowań jako decydującym o jakości życia osoby z niepełnosprawnością. Stąd apel o taką analizę tematyki niepełnosprawności, która $\mathrm{z}$ należnym szacunkiem uwzględniałaby równoprawność i równowartościowość wszelkich determinantów zagadnienia niepełnosprawności. Jedynie wskazane podejście może przyczynić się do poznania istoty niepełnosprawności i zaproponowania niepełnosprawnym rozwiązań systemowych adekwatnych istocie ich niepełnosprawności w kontekście ogólnym, globalnym oraz istocie niepełnosprawności w kontekście indywidualnym, jednostkowym.

\section{Piśmiennictwo:}

1. Majewski T. Biopsychospołeczna koncepcja niepełnosprawności. Szkoła Specjalna, 1999; 3: 131-4.

2. Międzynarodowa Klasyfikacja Funkcjonowania, Niepełnosprawności i Zdrowia (ICF) oraz jej zastosowanie. Warszawa: Centrum Systemów Informacyjnych Ochrony Zdrowia; 8.10.2007. Materiały robocze na CD.

3. Europejska strategia w sprawie niepełnosprawności 2010-2020: Odnowione zobowiązanie do budowania Europy bez barier [COM/2010/0636 końcowy]. Bruksela: 15.11.2010, s. 3.

4. Uchwała Sejmu RP z 1 sierpnia 1997 r. Karta Praw Osób Niepełnosprawnych. Monitor Polski, 1997; 50, poz. 474 i 475: 970-1.

5. Majewski T. Plany na przyszłość. Dłonie i Słowo, 2001; Numer Jubileuszowy: 78-84.

6. Majewski T. Edukacja i rehabilitacja osób głuchoniewidomych. Warszawa: PZN, TPG; 1995.

7. Szczepankowski B. Język migowy jako środek porozumiewania się z osobami głuchoniewidomymi z zespołem Ushera. W: Zaorska M, red. Komunikacja alternatywna osób głuchoniewidomych. Toruń: Wydawnictwo Edukacyjne Akapit; 2008, s. $128-41$.
8. Krzemkowska Z. Alfabet brajlowski. W: Zaorska M, red. Komunikacja alternatywna osób głuchoniewidomych. Toruń: Wydawnictwo Edukacyjne Akapit; 2008, s. 145-51.

9. Florek A. System Komunikacji Obrazkowej PCS. W: Zaorska M, red. Komunikacja alternatywna osób głuchoniewidomych. Toruń: Wydawnictwo Edukacyjne Akapit; 2008, s. 175-89.

10. Podeszewska-Mateńko M. Piktogramy - istota, charakterystyka ogólna. W: Błeszyński J, red. Alternatywne i wspomagające metody komunikacji. Kraków: Oficyna Wydawnicza Impuls; 2006, s. 369-88.

11. Lechowicz A. System komunikacji symbolicznej Bliss - twórca systemu, budowa, użytkownicy, rozwój systemu w Polsce. W: Błeszyński J, red. Alternatywne i wspomagające metody komunikacji. Kraków: Oficyna Wydawnicza Impuls; 2006, s. 451-70.

12. Zaorska M. Alfabet punktowy do dłoni. W: Zaorska M, red. Komunikacja alternatywna osób głuchoniewidomych. Toruń: Wydawnictwo Edukacyjne Akapit; 2008, s. 157-61.

13. Celmer-Domańska J. Metoda Lorma. W: Zaorska M, red. Komunikacja alternatywna osób głuchoniewidomych. Toruń: Wydawnictwo Edukacyjne Akapit; 2008, s. 162-70. 